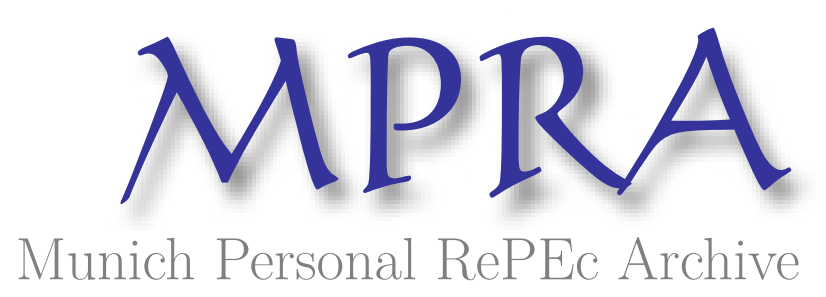

\title{
Structural changes in Brazil's industrial economy, 1960-80
}

Baer, Werner and Fonseca, Manuel A. R. da and Guilhoto, Joaquim José Martins

University of Illinois, Universidade de São Paulo

1986

Online at https://mpra.ub.uni-muenchen.de/54823/

MPRA Paper No. 54823, posted 27 Mar 2014 20:15 UTC 


\title{
Structural Changes in Brazil's Industrial Economy, 1960-80
}

\author{
WERNER BAER \\ and \\ MANUEL A. R. da FONSECA* \\ University of Illinois, Champaign-Urbana \\ JOAQUIM J. M. GUILHOTO* \\ University of Sao Paulo, Brazil
}

\begin{abstract}
Summary. - This paper examines the structural changes in Brazil's economy which can be observed through various censuses and input-output tables in the period 1960 to 1980 . The paper shows how the country's economy became more vertically integrated in those years, even though it has become more outward-oriented since the early days of import-substitution. It also considers the relations between the distribution of income and economic structure, both at present and in a possible future situation of redistribution.
\end{abstract}

\section{INTRODUCTION}

Brazil's intense import substitution industrialization (ISI) in the 1950s resulted in major structural changes in the economy as a whole and within the industrial sector. This development has been examined in previous studies, which have revealed that the type of ISI policies used promoted the appearance of many different industrial sectors, with special emphasis on those with high income and population elasticities and with high forward and backward linkages. ${ }^{1}$ After seven years of stagnation in the $1950 \mathrm{~s}$, Brazil again experienced extremely rapid growth rates in the late 1960s and early 1970s. Even after the first oil shock in 1973-74, relatively high general and industrial growth rates continued until $1981 .^{2}$ This growth was partially based on further import substitution (especially in such sectors as capital goods) and partially on the expansion of industrial exports and on vast investments in infrastructure projects. ${ }^{3}$

What type of changes in the structure of industry did this post-ISI period bring about? Did it continue or deviate from previous trends? How does the newer structure of Brazil's industrial economy compare to international benchmarks based on cross-section studies? And what do the observed structural changes imply for future growth patterns of Brazil's economy, considering especially the desire of the new civilian regime, which came into power in March 1985, to improve equity?

It is now possible to begin addressing such questions because of the availability of industrial censuses for the years 1970, 1975 and 1980, and of input-output tables for the years 1959, 1970 and 1975.

We shall begin by summarizing some of the traditional analyses of the relation between growth and structural change. Then, we will examine the Brazilian data. Finally, we shall speculate on the extent to which Brazil's changing industrial structure conforms to or deviates from the expected norms and what this implies for future growth prospects.

\section{GENERAL STRUCTURAL CHANGES}

The well-known Kuznets cross-section analysis, reproduced in Tables 1 and 2, clearly shows an inverse correlation between per capita income and the share of the agricultural sector, and a positive association of the share of industry and

\footnotetext{
*These authors would like to acknowledge the support of CAPES (Brazilian Ministry of Education) and CNPq (Brazilian National Science Council) in carrying out their research, part of which was used in writing this article.
} 
Table la. Kuznets cross-section data: Shares of production sectors in gross domestic product (percentage)

\begin{tabular}{|c|c|c|c|c|c|c|c|c|}
\hline & I & II & III & IV & V & VI & VII & VIII \\
\hline $\begin{array}{l}\text { GDP per capita }(\$) \\
(1958 \text { prices })\end{array}$ & 51.8 & 82.6 & 138 & 221 & 360 & 540 & 864 & 1,382 \\
\hline Agriculture & 53.6 & 44.6 & 37.9 & 32.3 & 22.5 & 17.4 & 11.8 & 9.2 \\
\hline Industry & 18.5 & 22.4 & 24.6 & 29.4 & 35.2 & 39.5 & 52.9 & 50.2 \\
\hline Services & 27.9 & 33.0 & 37.5 & 38.3 & +2.3 & 43.1 & 35.3 & +0.6 \\
\hline
\end{tabular}

Source: Kuznets (1971), p. 104.

*Based on cross-section analysis of 57 countries in 1958.

Table 1b. Brazil: Sectoral distribution of GDP (percentages)

\begin{tabular}{|c|c|c|c|c|c|c|c|c|}
\hline & 1953 & 1960 & 1965 & 1970 & 1975 & 1980 & 1982 & 1983 \\
\hline Agriculture & 26 & 23 & 19 & 11.7 & 9.7 & 8.8 & 9.1 & 12.0 \\
\hline Industry & 24 & 25 & 33 & 35.4 & 36.8 & 38.2 & 36.7 & 35.0 \\
\hline (Manufact.) & & & $(26)$ & $(28.0)$ & $(29.0)$ & $(29.0)$ & $(27.0)$ & $(27,0)$ \\
\hline Services & 50 & 52 & 48 & 52.9 & 53.5 & 53.0 & 54.2 & 53.0 \\
\hline
\end{tabular}

Source: Conjuntura Economica.

Table 2a. Kuznets cross-section data: Shares of labor force in production sectors

\begin{tabular}{lrrrrrrrrr}
\hline & I & II & III & IV & V & VI & VII & VIII \\
\hline GDP per capita (\$) & 72.3 & 107 & 147 & 218 & 382 & 588 & 999 & 1.501 \\
Agriculture & 79.7 & 63.9 & 66.2 & 59.6 & 37.8 & 21.8 & 18.9 & 11.6 \\
Industry & 9.9 & 15.2 & 16.0 & 20.1 & 30.2 & $4(0.9$ & 47.2 & 4.8 .1 \\
Services & 10.4 & 20.9 & 17.8 & 20.3 & 32.0 & 37.3 & 33.9 & $4(0.3$ \\
\hline
\end{tabular}

Source: Kuznets (1971), p. 200.

Table 2b. Brazil: Sectoral distribution of labor (percentages)

\begin{tabular}{lllll}
\hline & 1950 & 1960 & 1965 & 1981 \\
\hline Agriculture & 62 & 48 & 49 & 30 \\
Industry & 13 & 14 & 17 & 24 \\
Services & 25 & 38 & 34 & 46 \\
\hline
\end{tabular}

Source: Conjuntura Economica. services with per capita income. The Brazilian trend is in the same direction, as can be seen in Table 1b. The per capita income of Brazil in the early 1950 s was probably the equivalent of the Kuznets level between IV and $V$, which would make the Brazilian agricultural sector conform to the cross-section results, while the industrial share would seem to be somewhat smaller for the level of per capita GDP. If we assume that by the early 1980s Brazil's per capita GDP level fell 
belweell groups VI and VII, then the decline of agriculture was slightly larger than the crosssection results, but the share of industry was somewhat smaller than expected. ${ }^{4}$

A comparison of changes in the labor force distribution in Table 2 shows that agricultural employment was proportionally large in comparison with Kuznets" international benchmark, while industry's absorption of labor was smaller. both in the 1950s and 1980s.

\section{BRAZIL'S POST-WORLD WAR II INDUSTRIAL HISTORY}

Brazil's industrialization experience from World War II to the early 1980s can be divided into two broad periods: the years $1950-62$ and 1968-81. The former was a period of intensive import substitution industrialization in which industries were created across-the-board, though the emphasis was on consumer goods industries. with basic industries growing at significant, though lower rates. After about six years of stagnation and adjustments in the 1960 s, Brazil's economy experienced a boom from 1968 to 1973 , with industry being the leading sector, and from 1973 to 1981 strong growth rates continued, though at a more modest rate. In that period there occurred substantial import substitution in heavier industries and exports also bccamc an increasingly important source of demand for Brazil's industries.

Although a comparison of trends in the two periods cannot be made on the basis of inputoutput analysis, since the first table available dates only from 1959 , it is worthwhilc to get an idea from general information gathered from Brazilian censuses between 1950 and 1980. This can be obtained from Tables 1 through 4 .

It will be noted in Table $1 \mathrm{~b}$ that by 1960 industry's contribution to the GDP was $25 \%$, surpassing agriculture's share of $23 \%$ : but Table $2 \mathrm{~b}$ shows that employment in industry in 1960 was only $14 \%$ of the economically active population. while that of agriculture was $48 \%$. Comparing changes in the industrial structure (Table 3) between 1949 and 1963, one finds the most significant growth in the transportation and electrical equipment sectors, along with a more modest proportional growth of metal products and machinery. reflecting the lower priority given to capital goods at that time. There was also a notable expansion of the chemical/ pharmaceutical/perfumes/plastic sector, though it is difficult to determine which subsector was most important.

The proportional employment growth (see
Table 4) was relativcly small in transport and electrical equipment, though in metal products and machinery the value added and employment proportions were about the same. The most notable decline of employment share was in textiles and food, though it was not as great during this decade as the decline in valuc added.

At the end of the decade one would expect a fairly diversified industrial structure, but one which is not yet well interconnectcd, as vertical integration was only beginning.

During the second growth period, from the late 1960 s to the carly 1980 s, the most notable change in the country's industrial structure was the proportional growth of machinery and chemicals, the decline of textiles and food/beverages. and the proportional stability of electrical equipment, while transport declined slightly. This reflects the greater verticalization of Brazil's economy. Proportional employment growth was especially notable in the machinery and electrical cquipment scctors, while the biggest declines occurred in textiles.

A comparison of the changing Brazilian industrial structure with the Kuznets cross-section results (see Table 5) reveals some interesting differences. It will be noted that in Brazil the share of textiles, food, clothing/shoes and beverages followed a trend similar to that of the Kuznets data, though the absolute Brazilian shares are considerably lower than the shares expected from the cross-section results on the relevant per capita GDP level (i.e., around $\$ 500$ in 1958 prices). On the other hand, heavy industries (including metal products, transport equipment, etc.) and chemical products had a much greater than expected share. Given our current knowledge of the Brazilian economy, this greater emphasis on heavy industrial products and consumer durables than expected from international comparisons, suggests that the consumption, and thus production, pattern of Brazil was not only affected by the level of per capita income reached, but also by its uneven distribution. As the latter is worse than the international average, one would expect a greater demand for and production of consumer durables.

\section{STRUCTURAL CHANGES: $1959-80$}

Let us examine the structural changes which took place between the end of the ISI period of the 1950s and the industrialization spurt which began in the late $1960 \mathrm{~s}$. We do this through the prism of the input-output tables which are available for three years - 1959,1970 and 1975 . 
Table 3. Changes in Brazil's industrial structure: 1949-80 Gross value added (percentage distribution)

\begin{tabular}{lrrrr}
\hline & 1949 & 1963 & 1975 & 1980 \\
\hline Non-metallic minerals & 7.4 & 5.2 & 6.2 & 5.8 \\
Metal products & 9.4 & 12.0 & 12.6 & 11.5 \\
Machinery & 2.2 & 3.2 & 10.3 & 10.1 \\
Electrical equipment & 1.7 & 6.1 & 5.8 & 6.3 \\
Transport equipment & 2.3 & 10.5 & 6.3 & 7.6 \\
Wood products & 6.1 & 4.0 & 2.9 & 2.7 \\
Furniture & & & 2.0 & 1.8 \\
Paper products & 2.1 & 2.9 & 2.5 & 3.0 \\
Rubber products & 2.0 & 1.9 & 1.7 & 1.3 \\
Leather products & 1.3 & 0.7 & 0.5 & 0.6 \\
Chemicals & & & 12.0 & 14.7 \\
Pharmaceuticals & 9.4 & 15.5 & 2.5 & 1.6 \\
Perfumes, soap, candles & & & 1.2 & 0.9 \\
Plastic products & & & 2.2 & 2.4 \\
Textiles & 20.1 & 11.6 & 6.1 & 6.4 \\
Clothing and shoes & 4.3 & 3.6 & 3.8 & 4.8 \\
Food products & 19.7 & 14.1 & 11.3 & 10.0 \\
Beverages & 4.3 & 3.2 & 1.8 & 1.2 \\
Tobacco & 1.6 & 1.6 & 1.0 & 0.7 \\
Printing and publishing & 4.2 & 2.5 & 3.6 & 2.6 \\
Miscellaneous & 1.9 & 1.4 & 3.7 & 4.0 \\
& & & & \\
Total & 100.0 & 100.0 & 100.0 & 100.0 \\
& & & & \\
\hline
\end{tabular}

Source: IBGE, Industrial Censuses.

Table 4. Changes in Brazil's industrial employment structure, 1950-80 (percentage distribution)

\begin{tabular}{lrrrr}
\hline & 1950 & 1960 & 1975 & 1980 \\
\hline Non-metallic minerals & 9.7 & 9.7 & 8.4 & 8.8 \\
Metal products & 7.9 & 10.2 & 11.6 & 10.8 \\
Machinery & 1.9 & 3.3 & 10.2 & 10.9 \\
Electrical equipment & 1.1 & 3.0 & 4.6 & 8.7 \\
Transport equipment & 1.3 & 4.3 & 5.8 & 5.7 \\
Wood products & 4.9 & 5.0 & 5.3 & 5.3 \\
Furniture & 2.8 & 3.6 & 3.6 & 3.6 \\
Paper products & 1.9 & 2.4 & 2.2 & 2.2 \\
Rubber products & 0.8 & 1.0 & 1.2 & 1.1 \\
Leather products & 1.5 & 1.5 & 0.9 & 0.8 \\
Chemicals & 3.7 & 4.1 & 3.3 & 3.3 \\
Pharmaceuticals & 1.1 & 0.9 & 0.9 & 0.7 \\
Perfumes, soap, candles & 0.8 & 0.7 & 0.6 & 0.5 \\
Plastic products & 0.2 & 0.5 & 2.1 & 2.4 \\
Textiles & 27.4 & 20.6 & 8.8 & 7.7 \\
Clothing and shoes & 5.6 & 5.8 & 7.9 & 9.4 \\
Food products & 18.5 & 15.3 & 13.1 & 12.6 \\
Beverages & 2.9 & 2.1 & 1.4 & 1.2 \\
Tobacco & 1.3 & 0.9 & 0.6 & 0.4 \\
Printing and publishing & 3.0 & 3.0 & 3.3 & 2.9 \\
Miscellaneous & 1.7 & 2.1 & 4.2 & 4.0 \\
& & & & \\
Total & 100.0 & 100.0 & 100.0 & 100.0 \\
\hline
\end{tabular}

Source: IBGE, Industrial Censuses. 
Table 5. Kuznets cross-section data: Shares in manufacturing value added (percentages)

\begin{tabular}{|c|c|c|c|c|c|c|}
\hline \multirow{3}{*}{$\begin{array}{l}1953 \$: \\
1958 \$:\end{array}$} & \multicolumn{6}{|c|}{ Benchmark values of GDP per capita } \\
\hline & 81 & 135 & 270 & 450 & 900 & 1,200 \\
\hline & 91.7 & 153 & 306 & 510 & 1,019 & 1.359 \\
\hline \multicolumn{7}{|l|}{ Food, beverages } \\
\hline and tobacco & 33.8 & 37.4 & 34.8 & 27.2 & 17.6 & 15.5 \\
\hline Textiles & 18.3 & 14.2 & 10.5 & 9.4 & 7.1 & 5.6 \\
\hline Clothing and footwear & 4.8 & 6.3 & 7.8 & 7.5 & 6.3 & 5.5 \\
\hline Wood products and furniture & 6.9 & 5.4 & 4.9 & 5.1 & 5.7 & 5.4 \\
\hline Paper and paper products & 0.9 & 1.3 & 1.9 & 2.9 & 3.9 & 4.3 \\
\hline Printing and publishing & 2.5 & 2.6 & 2.9 & 3.5 & 4.7 & 5.3 \\
\hline \multicolumn{7}{|l|}{ Leather products } \\
\hline (excl. footwear) & 1.1 & 1.3 & 1.2 & 1.1 & 0.8 & 0.7 \\
\hline Rubber products & 1.2 & 1.4 & 1.2 & 1.3 & 1.4 & 1.4 \\
\hline \multicolumn{7}{|l|}{ Chemicals and petroleum } \\
\hline products & 8.7 & 9.3 & 9.7 & 9.6 & 8.9 & 9.3 \\
\hline \multicolumn{7}{|l|}{ Non-metallic mineral } \\
\hline products & 5.4 & 5.5 & 4.9 & 4.8 & 4.7 & 4.5 \\
\hline Basic metals & 4.0 & 3.5 & 4.3 & 5.2 & 5.7 & 6.0 \\
\hline Metal products & 10.4 & 9.9 & 13.7 & 19.8 & 29.8 & 32.8 \\
\hline Miscellaneous & 2.0 & 1.9 & 2.2 & 2.6 & 3.4 & 3.7 \\
\hline Total & 100.0 & 100.0 & 100.0 & 100.0 & 100.0 & 100.0 \\
\hline
\end{tabular}

Source: Kuznets (1971), p. 114.

This permits us to observe changes after allowing for total intersectoral repercussions.

\section{(a) Productive structure}

Table 6 contains the share of two-digit sectors" total output of the economy. It will be noted that the share of capital goods, consumer durables and intermediary goods (except paper and rubber products) increased in the years 1959-75, while non-durables (except for clothing and shoes) and agriculture declined. These structural changes are linked to the industrialization trends of the economy and to the increased concentration of income which accompanied it.

\section{(b) The final demand structure}

Table $7 \mathrm{a}$ contains the share of various sectors in total personal consumption (excluding imports). Most notable is the decline of raw agricultural products and the rise of processed foods. Sectors constituting durable consumer goods increased their share substantially, while the share of non-durable goods fell drastically (except clothing/shoes and processed foods). A probable explanation for this trend is the in- creased concentration of income during this period.

The stable share of clothing and footwear is closely related to the decline of textiles, reflecting the decline of home production of clothing. Explanations for the changing shares of other sectors are: (i) the rising share of the machinery sector reflects increased consumption of durable goods (refrigerators, washing machines, office equipment, etc.); (ii) the rising share of transportation is explained by the growing consumption of automobiles and parts; (iii) the higher share of the chemical sector reflects increased consumption of gasoline, liquid gas and other petroleum derivatives.

Table $7 \mathrm{~b}$ shows changes in the proportion of production destined for personal consumption in each sector. The declining shares in each sector signify a rising trend in the interdependence of sectors which occurred in the years 1959-75.

According to Hirschman (1958), this type of structural change is usually associated with the intensification of the industrialization process, i.e., the higher per capita income and the share of the population employed in the industrial sector, the greater will be intersectoral transactions. $^{6}$

The drastic decline noted in non-metallic minerals is due to a methodological change in the 
Table 6. Producrion strucaure (percenage distribution)

\begin{tabular}{|c|c|c|c|}
\hline & 1959 & 1970 & 1975 \\
\hline Agriculture & 16.23 & 11.11 & 9.43 \\
\hline Mining & 1.10 & 0.75 & 0.63 \\
\hline Non-metallic minerals & 1.86 & 1.90 & 1.92 \\
\hline Metal products & +.98 & 5.71 & 6.28 \\
\hline Machinery & 1.73 & 2.61 & 3.79 \\
\hline Electrical equipment & 1.87 & 2.14 & 2.40 \\
\hline Transport equipment & 3.38 & 3.80 & 4.24 \\
\hline Wood & 1.06 & 1.04 & 1.05 \\
\hline Wood products & 0.74 & 0.81 & 0.74 \\
\hline Paper & 1.26 & 1.09 & 1.10 \\
\hline Rubber & 1.02 & 0.77 & 0.79 \\
\hline Leather & 0.43 & 0.30 & 0.23 \\
\hline Chemicals & 7.22 & 5.09 & 7.36 \\
\hline Pharmaceuticals & 0.85 & 0.98 & 0.73 \\
\hline Cosmetics & 0.62 & 0.63 & 0.48 \\
\hline Plastics & 0.27 & 0.76 & 0.88 \\
\hline Textiles & 5.03 & +.10 & 3.41 \\
\hline Clothing and footwear & 1.37 & 1.55 & 1.47 \\
\hline Food & 9.84 & 10.71 & 7.97 \\
\hline Beverages & 0.97 & 0.75 & 0.62 \\
\hline Tobacco & 0.45 & 0.45 & 0.39 \\
\hline Printing & 0.95 & 1.19 & 1.08 \\
\hline Other Ind products & 0.58 & 1.06 & 1.02 \\
\hline Public utilities & 0.93 & 2.25 & 2.32 \\
\hline Construction & 6.08 & 10.73 & 10.14 \\
\hline Trade margins & 16.17 & 18.56 & 14.98 \\
\hline Services & 13.01 & 9.14 & 14.53 \\
\hline Total: & 100.00 & 100.00 & 100.00 \\
\hline
\end{tabular}

Source: For 1959, van Rijckeghem (1969); for 1970, IBGE (1979); for 1975, IBGE (1984c).

construction of the input-output table. This sector consists mainly of construction materials (especially cement). In the 1970 and 1975 matrices these products were treated as inputs into construction: this was not the case with the 1959 matrix.

Table 8 shows the share of exports in total output for each sector. These proportions clearly show that there was a substantial opening of the Brazilian economy in the period 1959-75, especially for sectors like metal products, machinery, transport equipment, paper products and chemicals. The column for 1981 is not strictly comparable with the others, since the export proportions were taken directly from raw export value and value of output statistics. However, the numbers do indicate a further substantial growth of exports in some of the key sectors of the industrial economy. This is consistent with the fact that in the mid- 1980 s over $50 \%$ of Brazil's exports consisted of manufactured products.
Table 7a. Personal consumption stracture of domesically prodaced goods

\begin{tabular}{|c|c|c|c|}
\hline & 1959 & $1971)$ & 1975 \\
\hline Agriculture & 17.40 & 5.40 & 3.33 \\
\hline Mining & 0.00 & 0.00 & (1).01 \\
\hline Non-metallic minerals & 0.51 & 11.18 & 0.07 \\
\hline Metal products & 0.41 & 0.92 & $0 .+4$ \\
\hline Machinery & 10.32 & 1.117 & 1.20 \\
\hline Electrical equipment & 1.83 & 0.92 & 1.93 \\
\hline Transport equipment & 0.79 & 2.89 & 51.3 \\
\hline Wood & 0.09 & 0.02 & 0.03 \\
\hline Wood products & 1.34 & 1.98 & 1.58 \\
\hline Paper & 0.11 & 0.22 & (1). 19 \\
\hline Rubber & 0.96 & 0.16 & 0.18 \\
\hline Leather & 0.11 & 0.08 & $0.0 !$ \\
\hline Chemicals & 0.96 & 2.22 & 3.93 \\
\hline Pharmaceuticals & 1.56 & 2.29 & 1.54 \\
\hline Cosmetics & 1.31 & 1.94 & 2.30 \\
\hline Plastics & $0 .+2$ & 0.03 & 0.03 \\
\hline Textiles & 6.88 & 1.28 & 1.99 \\
\hline Clothing and footweal & 3.11 & 3.54 & 3.33 \\
\hline Food & 15.14 & 25.34 & 21.12 \\
\hline Beverages & 2.01 & 1.63 & 0.37 \\
\hline Tobacco & 0.87 & 1.28 & 0.82 \\
\hline Printing & 1.21 & 0.55 & 0.76 \\
\hline Other Ind. products & 1.03 & 1.03 & 0.88 \\
\hline Public utilities & 0.27 & 3.15 & +.55 \\
\hline Construction & $2 .+2$ & 0.00 & 0.00 \\
\hline Trade margins & 20.28 & 35.48 & 30.88 \\
\hline Services & 18.67 & 6.37 & 13.37 \\
\hline Total & 100.00 & 100.00 & 100.00 \\
\hline
\end{tabular}

Source: For 1959. van Rijckeghem (1969); for 1970. IBGE (1979): for 1975. IBGE (1984c).

\section{(c) Production technology}

It has been shown that the industrialization process of the 1950s made use of large quantities of second-hand equipment from advanced industrial countries. By the 1970 s, this changed considerably as most sectors incorporated the latest technology into their expansion plans. ${ }^{7}$ Our data in Tables $9 \mathrm{a}, 9 \mathrm{~b}$ and 10 are consistent with these events, i.e., in most sectors the share of labor in value added has declined and the installed power per worker has increased. ${ }^{8}$ This trend supports the contention of a number of scholars that real wage increases in the Brazilian economy have little influence on the inflationary process, ${ }^{9}$ and that wage restraints should therefore not be the centerpiece of a stabilization program.

Exceptions to these general trends, where sectors experienced an increase in the share of salaries in the value of total production, are: mining, machinery, public utilities, construction 
Table 7b. Share of personal consumption in total production

\begin{tabular}{lrrr}
\hline & 1959 & 1970 & 1975 \\
\hline Agriculture & 45.03 & 14.39 & 6.24 \\
Mining & 0.00 & 0.00 & 0.32 \\
Non-metallic minerals & 11.57 & 2.84 & 0.61 \\
Metal products & 3.47 & 4.78 & 1.39 \\
Machincry & 7.68 & 12.17 & 5.61 \\
Electrical equipment & 41.10 & 12.80 & 14.21 \\
Transport equipment & 9.84 & 22.50 & 21.37 \\
Wood & 3.51 & 0.67 & 0.48 \\
Wood products & 76.42 & 72.16 & 37.56 \\
Paper & 3.61 & 5.88 & 3.13 \\
Rubber & 39.76 & 6.16 & 3.95 \\
Leather & 10.75 & 8.33 & 0.56 \\
Chemicals & 5.59 & 12.93 & 9.43 \\
Pharmaceuticals & 77.24 & 68.98 & 37.44 \\
Cosmetics & 89.22 & 90.62 & 84.44 \\
Plastics & 64.84 & 1.19 & 0.63 \\
Textiles & 57.43 & 9.25 & 10.33 \\
Clothing and footwear & 95.79 & 67.76 & 39.97 \\
Food & 64.63 & 70.01 & 46.84 \\
Beverages & 86.90 & 64.12 & 10.43 \\
Tobacco & 81.66 & 83.78 & 37.44 \\
Printing & 53.71 & 13.67 & 12.33 \\
Other Ind. products & 75.22 & 28.76 & 15.17 \\
Public utilities & 11.97 & 41.30 & 34.62 \\
Construction & 16.72 & 0.00 & 0.00 \\
Trade/transport & 52.67 & 56.58 & 36.47 \\
Services & 60.25 & 20.60 & 16.27 \\
& & & \\
\hline & & & \\
\hline
\end{tabular}

Source: For 1959. van Rijckeghem (1969); for 1970. IBGE (1979); for 1975. IBGE (1984c).

and services (see Table 9a). Sectors which seemed to have been using more labor-intensive technology (according to wages and social security payments as a share of value added) are: rubber products, public utilities and construction (Table 9b). Table 10, which shows installed power capacity per worker. reveals that all sectors experienced increased growth in capital intensity when using this criterion.

Table 11, which shows the share of imported inputs in the value of total production, reveals a downward trend for most sectors. The exceptions are chemicals. pharmaceuticals, plastics, rubber and cosmetics. The trend reflects the increascd complexity of the Brazilian economy, which has resulted in an increased degree of intersectoral linkages. as discussed below. The exceptions are sectors which depend on very specialized foreign inputs. which cannot be substituted in the short run.

\section{(d) Backward and forward linkages}

Tables 12a and 12b contain Rasmussen's forward and backward linkage indexes for the Brazilian economy at different periods. ${ }^{10}$ These indexes show that in 1959 three sectors (paper, chcmicals and textiles) had high forward and backward linkages and accounted for $13.51 \%$ of the economy's total output. In 1970 and 1975, the number of sectors with high linkages increased to five (metal products, machinery, paper, textiles and food products) and accounted for $24.22 \%$ and $22.55 \%$ of total output in 1970 and 1975 , respectively. It is interesting to note that sectors which previously had relatively little importance in the industrialization process in the initial ISI era - metal products, machinery and food and which subsequently became leading sectors were those which by their nature contributed to increasing intersectoral linkages. The process of industrialization also produced changes in the backward linkage capacity of various sectors. That is, sectors which previously had low backward linkages due to the high proportion of imported inputs began to buy an increasing amount of these inputs domestically. This is revealed in the growth of backward linkage capacity of such sectors as metal products, machinery and transport equipment. Also, contradicting the observations of Hirschman (1958, p. 109), the agricultural sector developed high forward linkages."

A comparison of data for Brazil in 1959 with data for Sri Lanka. Taiwan, Malaysia and South Korea in the early $1960 \mathrm{~s},{ }^{12}$ reveals that the values for forward and backward linkages are larger for Brazil, which indicates a greater degrec of internal linkages within the Brazilian economy. This would tend to support a previous study of the Brazilian economy which used linkage rankings for the US economy. ${ }^{13}$

\section{GENERAL CONCLUSIONS}

Our study of the changing structure of the Brazilian economy and the changing nature of its intersectoral relationships has shown that the vertical integration of the economy has increased significantly since the early ISI days of the 1950s. It is noteworthy, however, that this trend did not increase the country's economic autarky. On the contrary, increased vertical integration occurred at the same time as the degree of outwardorientedness of the Brazilian economy increased. especially when observed from the point of view of the export share of various industrial sectors. Most sectors have experienced a rising share of 
Taule 8. Share of exports in total production (percentages)

\begin{tabular}{|c|c|c|c|c|}
\hline & 1959 & 1970 & 1975 & $1981^{*}$ \\
\hline Agriculture & 2.56 & 3.88 & +.80 & n.a. $\dagger$ \\
\hline Mining & 8.00 & 25.94 & 39.33 & n.a. \\
\hline Non-metallic minerals & 0.37 & 0.92 & 0.79 & 2.00 \\
\hline Metal products & 0.01 & 3.63 & 1.69 & 6.00 \\
\hline Machinery & 0.30 & 4.11 & 3.10 & 8.10 \\
\hline Electrical equipment & 0.02 & 1.50 & 4.55 & n.a. \\
\hline Transport equipment & 0.09 & 0.83 & 4.83 & 15.00 \\
\hline Wood & 0.25 & 16.24 & 3.87 & 6.70 \\
\hline Wood products & 0.00 & 0.34 & 0.72 & na. \\
\hline Paper & 0.00 & 1.04 & 2.38 & n.a. \\
\hline Rubber & 0.12 & 1.01 & 1.27 & n.a. \\
\hline Leather & 16.09 & 15.49 & 11.14 & 23.00 \\
\hline Chemicals & 3.13 & 6.48 & 6.85 & 1.90 \\
\hline Pharmaceuticals & 0.23 & 0.96 & 0.78 & n.a. \\
\hline Cosmetics & 0.01 & 0.19 & 0.30 & n.a. \\
\hline Plastics & 0.03 & 0.05 & 0.33 & 4.80 \\
\hline Textiles & 0.62 & 8.42 & 5.79 & 18.30 \\
\hline Clothing and footwear & 0.07 & 1.14 & 8.30 & 16.40 \\
\hline Food & 21.71 & 15.20 & 10.02 & 18.70 \\
\hline Beverages & 0.05 & 0.31 & 0.27 & n.a. \\
\hline Tobacco & 1.01 & 13.10 & 18.55 & n.a. \\
\hline Printing & 0.27 & 0.36 & 0.71 & n.a. \\
\hline Other Ind. products & 0.33 & 1.55 & 2.73 & n.a. \\
\hline Public utilities & 0.01 & 0.00 & 0.00 & n.a. \\
\hline Construction & 0.00 & 0.00 & 0.00 & n.a. \\
\hline Trade/transport & 7.09 & 5.51 & 8.15 & n.a. \\
\hline Services & 0.00 & 0.59 & 0.00 & n.a. \\
\hline
\end{tabular}

Source: For 1959, van Rijckeghem (1969); for 1970, IBGE (1979); for 1975, IBGE (1984c); for 1981, IBGE (1984a).

*The 1981 proportions are not strictly comparable to the previous years, since they are based on gross export and value of output data from IBGE (1984a).

tn.a. - not available.

exports in their total output. This probably reflects a positive response to various export incentives which the government introduced during the $1960 \mathrm{~s}$ and $1970 \mathrm{~s}^{14}$ and also the capacity to compete on the international market. both price and quality-wise.

One should especially note that a growing number of Brazilian exports consist of semifinished and capital goods, exported either by individual Brazilian firms or by subsidiaries of multinationals. The latter often send components produced in Brazil to other manufacturing plants in their organization. This explains, in part. why vertical integration is not a movement against international trade. One could envision in the long run an exchange of goods at various levels of the production process, i.e., growing international exchange of both finished and intermediate goods. Given the development of the Brazilian economy, with its size, diversity of resources and of industrial structure, verticalization and trade growth could easily continue in the future.

A growing internationalization of the economy will also at some point have to imply an end to the declining import coefficient of different sectors. As the weight of Brazil in international trade grows, permanent trade surpluses will be less and less feasible and the Brazilian economy will also have to accept some international specialization within the spectrum of final industrial products and intermediate goods. That is, Brazil would have to accept the importation of certain industrial goods as a permanent feature. as these would be the counterpart of a permanent acceptance of Brazilian industrial goods in the markets of older industrial nations.

The current productive structure of the Brazi- 
Tablc 9a. Share of wages and social security in total production (percentages)

\begin{tabular}{lrrrr}
\hline & 1959 & 1970 & 1975 & 1980 \\
\hline Agriculture & 19.89 & 16.85 & 15.58 & n.a. $^{*}$ \\
Mining & 12.69 & 27.23 & 13.08 & 15.10 \\
Non-metallic minerals & 20.86 & 20.65 & 14.38 & 14.50 \\
Metal products & 13.47 & 13.13 & 10.59 & 9.64 \\
Machinery & 15.37 & 24.24 & 20.85 & 24.27 \\
Electrical equipment & 12.95 & 17.39 & 12.65 & 12.25 \\
Transport equipment & 11.04 & 15.90 & 10.62 & 10.75 \\
Wood & 17.73 & 17.89 & 14.27 & 15.40 \\
Wood products & 22.85 & 22.02 & 17.15 & 17.10 \\
Paper & 11.01 & 15.98 & 10.64 & 9.33 \\
Rubber & 9.05 & 12.07 & 8.29 & 9.45 \\
Leather & 15.10 & 15.49 & 14.02 & 13.07 \\
Chemicals & 4.64 & 8.79 & 3.48 & 3.14 \\
Pharmaceuticals & 15.20 & 12.78 & 8.99 & 8.43 \\
Cosmetics & 8.11 & 8.33 & 6.04 & 6.66 \\
Plastics & 14.18 & 13.60 & 11.54 & 11.40 \\
Textiles & 17.71 & 16.59 & 10.14 & 10.09 \\
Clothing and footwear & 17.83 & 16.83 & 15.38 & 14.95 \\
Food & 6.64 & 8.98 & 5.21 & 5.98 \\
Beverages & 15.04 & 18.69 & 9.60 & 11.61 \\
Tobacco & 9.66 & 10.32 & 8.04 & 8.10 \\
Printing & 23.38 & 26.92 & 19.36 & 21.40 \\
Other Ind. products & 21.28 & 14.17 & 8.92 & 13.49 \\
Public utilities & 4.36 & 31.58 & 30.36 & n.a. \\
Construction & 12.82 & 24.60 & 19.07 & n.a. \\
Trade/transport & 29.09 & 27.38 & 25.42 & $n . a$. \\
Services & 22.61 & 51.60 & 25.19 & $n . a$. \\
\hline
\end{tabular}

Source: For 1959, van Rijckeghem (1969); for 1970, IBGE (1979); for 1975, IBGE (1984c); for 1980, IBGE (1984b).

${ }^{*}$ n.a. - not available.

lian economy reflects a certain consumption structure, which, in turn, is associated with the existing distribution of income. Should the new civilian government implement a policy of income redistribution, one might expect changes in the structure of consumption and thus in the productive structure of the economy. In fact, in a simulation exercise, Locatelli (1985) found that a more egalitarian distribution of income (similar to that of the United Kingdom) would result in a $16 \%$ growth in Brazil's industrial employment. This would occur because the greater purchasing power of low income groups would increase the demand for goods with a greater labor-intensive technology. ${ }^{15}$ As a result, the possibility of economic growth would depend on a sectoral restructuring of the economy, with more emphasis placed on mass consumption goods and less emphasis on consumer durables. Given the present structure of the economy, growth would depend on current export levels.

Finally, as was shown in this essay, the share of wages in final prices has been continuously declining since the 1960s. It follows that the control of wage increases is not the crucial element for the success of stabilization programs.

\section{NOTES}

1. Baer (1965). Chap. 6.

2. Baer (1983). Chaps. 5 and 6.
3. Ibid.

4. Although the use of international cross-section 
Table 9b. Share of wages and social security in value added (percentages)

\begin{tabular}{lllll}
\hline & 1959 & 1970 & 1975 & 1980 \\
\hline Agriculture & 24.07 & 22.57 & 21.63 & n.a. \\
Mining & 35.99 & 34.18 & 19.16 & 23.60 \\
Non-metallic minerals & 37.46 & 33.26 & 24.87 & 25.56 \\
Metal products & 35.37 & 31.61 & 29.59 & 28.07 \\
Machinery & 47.76 & 42.14 & 41.47 & 44.37 \\
Electrical equipment & 38.72 & 33.40 & 28.07 & 24.44 \\
Transport equipment & 31.74 & 34.55 & 37.46 & 27.22 \\
Wood & 37.98 & 36.83 & 27.99 & 28.37 \\
Wood products & 49.37 & 40.60 & 33.84 & 34.43 \\
Paper & 30.00 & 34.55 & 27.43 & 20.25 \\
Rubber & 19.00 & 22.74 & 20.81 & 27.24 \\
Leather & 38.49 & 35.31 & 34.04 & 33.41 \\
Chemicals & 23.81 & 21.30 & 11.75 & 10.08 \\
Pharmaceuticals & 36.82 & 17.87 & 13.67 & 13.79 \\
Cosmetics & 25.37 & 16.52 & 12.88 & 15.24 \\
Plastics & 30.22 & 26.62 & 24.48 & 23.17 \\
Textiles & 42.51 & 34.97 & 29.38 & 24.72 \\
Clothing and footwear & 43.49 & 36.88 & 34.84 & 29.06 \\
Food & 26.46 & 30.46 & 19.49 & 20.18 \\
Beverages & 33.83 & 32.97 & 17.73 & 24.69 \\
Tobacco & 19.73 & 17.20 & 15.81 & 15.76 \\
Printing & 48.66 & 41.17 & 30.00 & 32.44 \\
Other Ind. products & 42.59 & 39.48 & 25.83 & 21.83 \\
Public utilities & 10.72 & 34.93 & 38.73 & $\mathrm{n} . \mathrm{a}$. \\
Construction & 41.55 & 61.51 & 61.83 & $\mathrm{n} . \mathrm{a}$. \\
Trade/transport & 44.94 & 33.67 & 32.24 & $\mathrm{n} . \mathrm{a}$. \\
Services & 27.62 & 61.98 & 29.52 & $\mathrm{n} . \mathrm{a}$. \\
\hline & & & & \\
\hline
\end{tabular}

Source: For 1959, van Rijckeghem (1969); for 1970, IBGE (1979): for 1975, IBGE (1984c); for 1980. IBGE (1984b).

*n.a. - not available.

analyses has generated considerable controversy in the literature, we feel that the Kuznets results still provide a useful benchmark for analyzing structural changes in the growth process. See Chenery and Syrquin (1974) and Sutcliffe (1971).

5. A good idea of the relative concentration of Brazil's income can be gained from the following data published by the World Bank. In the early 1980 s the highest $10 \%$ of the income groups were receiving: $50.6 \%$ of household income in Brazil; $40.6 \%$ in Mexico; $40.7 \%$ in Turkey; $33.6 \%$ in India; $34.0 \%$ in Indonesia; $23.3 \%$ in the US; and $24.0 \%$ in West Germany. See World Bank (1985), pp. 228-229.

6. Hirschman states that the ". . . lack of interdependence and linkage is of course one of the most typical characteristics of underdeveloped economies." See Hirschman (1958), p. 109.

7. Villela and Baer (1980), pp. 185-189.

8. In Tables $9 a$ and 96 value added was obtained using two different methodologies. In the 1959, 1970, and 1975 columns, value added was derived from input-output matrices, while for 1980 it was obtained from the Brazilian industrial census. Strict comparison between the first three and the last columns is thus impossible, but one can still get an idea of the general trends.

9. See. for instance. Macedo (1983). pp. 133-159.

10. Rasmussen (1956).

11. Hirschman claimed that ".. . Agriculture in general. and subsistence agriculture in particular, are of course characterized by the scarcity of linkage effects." I lirschman (1958), p. 109.

12. Laumas (1975), pp. 62-79

13. Baer (1965), pp. 138-144: sce also Huddle's early confirmation of the Baer study based on the 1959 input-output table. Huddle (1972), pp. 568-569. Many of our conclusions were also given support in a recent study (Locatelli, 1985).

14. Baer (1983). Chap. 5.

15. Locatelli (1985), pp. 166-171; see also Bonelli and De Cunha (1981), pp. 703-756. 
Table 10. Insialled power (HP)/workers

\begin{tabular}{|c|c|c|c|}
\hline & 1960 & 1970 & 1980 \\
\hline Agriculture & n.a.* & n.a. & n.a. \\
\hline Mining & 1.77 & 8.05 & 12.99 \\
\hline Non-metallic minerals & 3.15 & 4.86 & 6.15 \\
\hline Metal products & 4.26 & 9.62 & 8.57 \\
\hline Machinery & 2.89 & 3.80 & 4.52 \\
\hline Electrical equipment & 2.62 & 5.77 & 2.68 \\
\hline Transport equipment & 4.14 & 5.73 & $4.0(0)$ \\
\hline Wood & 4.54 & 4.96 & 7.15 \\
\hline Wood products & 2.07 & 2.62 & 3.60 \\
\hline Paper & 8.48 & 14.05 & 14.80 \\
\hline Rubber & 7.45 & 6.82 & 9.82 \\
\hline Leather & 3.27 & 4.94 & 5.49 \\
\hline Chemicals & 9.20 & 16.06 & 30.84 \\
\hline Pharmaceuticals & 3.08 & 3.80 & 3.51 \\
\hline Cosmetics & 2.18 & 3.73 & 3.47 \\
\hline Plastics & 3.68 & 4.08 & 4.73 \\
\hline Textiles & 2.50 & 4.00 & 5.04 \\
\hline Clothing and footwear & 0.61 & 1.29 & 1.56 \\
\hline Food & 5.46 & 6.86 & 7.30 \\
\hline Beverages & 4.05 & 5.58 & 7.79 \\
\hline Tobacco & 1.19 & 1.36 & 10.82 \\
\hline Printing & 1.30 & 3.13 & 2.09 \\
\hline Other Ind. products & 1.52 & 6.88 & 2.22 \\
\hline Public utilities & n.a. & n.a. & n.a. \\
\hline Construction & n.a. & n.a. & n.a. \\
\hline Trade margins & n.a. & n.a. & n.a. \\
\hline Services & n.a. & n.a. & n.a. \\
\hline
\end{tabular}

Source: Calculated from IBGE (1984a); Baer and Geiger (1978).

*n.a. - not available.
Table 11. Share of imported inputs in total producrion (percentages)

\begin{tabular}{|c|c|c|c|}
\hline & 1959 & 1970 & 1975 \\
\hline Agriculture & 3.13 & 0.52 & 0.54 \\
\hline Mining & 53.21 & 0.00 & 0.13 \\
\hline Non-metallic minerals & 3.67 & 0.92 & 1.32 \\
\hline Metal products & 15.53 & 2.04 & 5.05 \\
\hline Machinery & 33.99 & 3.40 & 3.72 \\
\hline Electrical equipment & 15.07 & 8.92 & 9.81 \\
\hline Transport equipment & 19.81 & 2.88 & 4.63 \\
\hline Wood & 0.24 & 0.34 & 0.36 \\
\hline Wood products & 0.03 & 0.19 & 0.21 \\
\hline Paper & 5.63 & 2.19 & 2.97 \\
\hline Rubber & 0.51 & 3.84 & 5.34 \\
\hline Leather & 0.38 & 1.04 & 1.22 \\
\hline Chemicals & 15.60 & 16.28 & 26.94 \\
\hline Pharmaceuticals & 8.22 & 8.48 & 10.22 \\
\hline Cosmetics & 1.03 & 3.15 & 6.05 \\
\hline Plastics & 0.15 & 9.88 & 3.72 \\
\hline Textiles & 0.31 & 0.99 & 0.81 \\
\hline Clothing and footwear & 0.08 & 0.35 & 0.28 \\
\hline Food & 1.87 & 2.35 & 2.49 \\
\hline Beverages & 2.51 & 3.37 & 6.02 \\
\hline Tobacco & 0.00 & 0.26 & 0.42 \\
\hline Printing & 3.86 & 5.25 & 3.48 \\
\hline Other Ind. products & 10.07 & 6.51 & 5.07 \\
\hline Public utilities & 0.00 & 0.19 & 1.23 \\
\hline Construction & 0.00 & 2.00 & 2.31 \\
\hline Trade/transport & 0.00 & 1.58 & 2.32 \\
\hline Services & 0.00 & 0.12 & 0.25 \\
\hline
\end{tabular}

Sources: For 1959, van Rijckeghem (1969); for 1970, IBGE (1979): for 1975, IBGE (1984c).

\section{REFERENCES}

Baer, Werner, Industrialization and Economic Development in Brazil (Homewood. Illinois: Richard D. Irwin. 1965).

Baer. Werner. The Brazilian Economy: Growth and Development. Second Edition (New York: Praeger. 1983).

Baer. Werner. and Pedro Pinchas Geiger. "Industrializacao, urbanizacao e a persistencia das desigualdades regionais no Brasil." in Werner Baer et al. (Eds.). Dimensoes do Desenvolvimento Brasileiro (Rio de Janeiro: Editora Campus Ltda., 1978).

Bonelli. R.. and P. Vieira De Cunha, "Crescimento Economico. Padrao de Consumo e Distribuicao de Renda no Brasil: Uma Abordagem Multisetorial para o Periodo 1970/5." Pesquisa e Planejamento Economico. Vol. 2, No. 3 (1981), pp. 703-756.

Chenery. H. B.. and M. Syrquin. Patlerns of Developmemi $1950-70$ (London: Oxford University Press, 1974).

Hirschman. A. O.. The Strategy of Economic Developmenl (New Haven: Yale University Press. 1958).

Huddle. Donald L.. "Review article: Essays on the economy of Brazil: The Berkeley Group." Economic Development and Cultural Change (April 1972), pp. 568-569.

IBGF, Matriz de Relacoes Intersetoriais - Brasil 1970. Versao Final (Rio de Janeiro: Fundacao Instituto Brasileiro de Geografia e Estatistica - IBGE, 1979).

IBGE, Anuario Estatistico (Rio de Janeiro: IBGE. 1984a).

IBGE. Censo Industrial de 1980 (Rio de Janeiro: IBGE. 1984b).

IBGE, Marriz de Relacoes Intersetoriais - Brasil 1975. Unpublished (Rio de Janeiro: Fundacao Instituto Brasileiro de Geografica e Estatistica, 1984c).

Kuznets. Simon. Economic Growth of Nations: Total Output and Production Structure (Cambridge, MA: Harvard University Press, 1971).

Laumas. P. S., "Key sectors in some underdeveloped countries," Kyklos, Vol. 28. No. 1 (1975), pp. 62-79.

Locatelli, Ronaldo Lamounier, Industrializacao. Crescimento e Emprego: Uma Avaliacao da Experiencia Brasileira (Rio de Janeiro: IPEA/INPES, 1985).

Macedo, Roberto. "Wage indexation and inflation: 
Table 12a. Index of backward linkage

\begin{tabular}{llll}
\hline & 1959 & 1970 & 1975 \\
\hline Agriculture & 0.6557 & 0.8200 & 0.8159 \\
Mining & 0.6291 & 0.7790 & 0.8261 \\
Non-metallic minerals & 0.9129 & 0.9302 & 0.9105 \\
Metal products & 0.9818 & 1.2176 & 1.1755 \\
Machinery & 0.8592 & 1.0151 & 1.0188 \\
Electrical equipment & 1.0302 & 1.0013 & 0.9854 \\
Transport equipment & 0.9679 & 1.1630 & 1.3158 \\
Wood & 0.9673 & 1.0548 & 0.9743 \\
Wood products & 1.0486 & 1.0654 & 1.0292 \\
Paper & 1.1675 & 1.1272 & 1.1462 \\
Rubber & 1.0123 & 1.0136 & 1.1002 \\
Leather & 1.0819 & 1.2154 & 1.1662 \\
Chemicals & 1.1470 & 0.9844 & 0.9275 \\
Pharmaceuticals & 1.0268 & 0.7828 & 0.7522 \\
Cosmetics & 1.2078 & 1.0866 & 1.0055 \\
Plastics & 1.0874 & 0.9718 & 1.0087 \\
Textiles & 1.0913 & 1.1008 & 1.2623 \\
Clothing and footwear & 1.1360 & 1.1797 & 1.1999 \\
Food & 1.1021 & 1.2689 & 1.2558 \\
Beverages & 1.0135 & 0.9916 & 0.9507 \\
Tobacco & 0.9731 & 0.9544 & 0.9993 \\
Printing & 1.0513 & 0.8927 & 0.8715 \\
Other Ind. products & 0.9207 & 1.1635 & 1.1400 \\
Public utilities & 1.1590 & 0.6821 & 0.7125 \\
Construction & 1.1760 & 1.0634 & 1.0815 \\
Trade/transport & 0.8725 & 0.7359 & 0.7035 \\
Services & 0.7210 & 0.7389 & 0.6649 \\
\hline & & & \\
\hline
\end{tabular}

Source: For 1959, van Rijckeghem (1969); for 1970 , IBGE (1979); for 1975, IBGE (1984c).

The recent Brazilian experience," in Rudiger Dornbusch and Mario H. Simonsen (Eds.), Inflation, Debt and Indexation (Cambridge, MA: The MIT Press, 1983), pp. 133-159.

Rasmussen, P. N., Studies in Inter-Sectoral Relations (Amsterdam: North Holland, 1956).

Sutcliffe, R. B., Industry and Underdevelopment (New York: Addison-Wesley Publishing Co., 1971). van Rijckeghem, Willy, "An intersectoral consistency
Table 12b. Index of forward linkage

\begin{tabular}{lccc}
\hline & 1959 & 1970 & 1975 \\
\hline Agriculture & 2.1446 & 2.1988 & 1.9060 \\
Mining & 0.9575 & 0.8000 & 0.7376 \\
Non-metallic minerals & 0.7873 & 0.8904 & 0.8409 \\
Metal products & 1.9181 & 2.0456 & 2.1030 \\
Machinery & 0.5705 & 1.0508 & 1.0107 \\
Electrical equipment & 0.6218 & 0.8719 & 0.8545 \\
Transport equipment & 0.6757 & 0.8635 & 0.9161 \\
Wood & 0.8997 & 0.8521 & 0.8969 \\
Wood products & 0.5478 & 0.6287 & 0.5729 \\
Paper & 1.3305 & 1.1803 & 1.1911 \\
Rubber & 0.7090 & 0.8010 & 0.8438 \\
Leather & 0.7605 & 0.7010 & 0.7282 \\
Chemicals & 2.9454 & 2.0118 & 2.4571 \\
Pharmaceuticals & 0.5647 & 0.6783 & 0.6089 \\
Cosmetics & 0.5460 & 0.6225 & 0.5702 \\
Plastics & 0.5970 & 0.8119 & 0.8085 \\
Textiles & 1.1620 & 1.3232 & 1.4488 \\
Clothing and footwear & 0.5449 & 0.6253 & 0.5735 \\
Food & 0.6993 & 1.2332 & 1.0175 \\
Beverages & 0.5817 & 0.6583 & 0.6026 \\
Tobacco & 0.6512 & 0.6230 & 0.6285 \\
Printing & 0.6366 & 0.6849 & 0.6368 \\
Other Ind. products & 0.5587 & 0.8338 & 0.7743 \\
Public utilities & 0.9592 & 0.8816 & 0.8092 \\
Construction & 0.6854 & 0.6193 & 0.5560 \\
Trade/transport & 1.9803 & 1.8433 & 2.2561 \\
Services & 1.9648 & 0.6655 & 0.6505 \\
& & & \\
\hline & & & \\
& & & \\
& & & \\
& & & \\
& & & \\
& & & \\
& & & \\
& &
\end{tabular}

Sources: For 1959, van Rijckeghem (1969); for 1970, IBGE (1979); for 1975, IBGE (1984c).

model for economic planning in Brazil," in $\mathrm{H}$. S. Ellis (Ed.), The Economy of Brazil (Berkeley and Los Angeles: University of California Press, 1969). Villela, Annibal, and Werner Baer. U Setor Privado Nacional: Problemas e Politicas Para Seu Fortalecimento (Rio de Janeiro: IPEAVINPES, 1980).

World Bank, World Development Report 1985 (New York: Oxford University Press, 1985). 